\title{
Host gene response to endosymbiont and pathogen in the cereal weevil Sitophilus oryzae
}

\author{
Aurélien Vigneron ${ }^{1}$, Delphine Charif ${ }^{2}$, Carole Vincent-Monégat ${ }^{1}$, Agnès Vallier ${ }^{1}$, Frédérick Gavory ${ }^{3}$, Patrick Wincker ${ }^{3}$,
} Abdelaziz Heddi ${ }^{*}$

\begin{abstract}
Background: Insects thriving on nutritionally poor habitats have integrated mutualistic intracellular symbiotic bacteria (endosymbionts) in a bacteria-bearing tissue (the bacteriome) that isolates the endosymbionts and protects them against a host systemic immune response. Whilst the metabolic and physiological features of long-term insect associations have been investigated in detail over the past decades, cellular and immune regulations that determine the host response to endosymbionts and pathogens have attracted interest more recently.

Results: To investigate bacteriome cellular specificities and weevil immune responses to bacteria, we have constructed and sequenced 7 cDNA libraries from Sitophilus oryzae whole larvae and bacteriomes.

Bioinformatic analysis of 26,886 ESTs led to the generation of 8,941 weevil unigenes. Based on in silico analysis and on the examination of genes involved in the cellular pathways of potential interest to intracellular symbiosis (i.e. cell growth and apoptosis, autophagy, immunity), we have selected and analyzed 29 genes using qRT-PCR, taking into consideration bacteriome specificity and symbiosis impact on the host response to pathogens. We show that the bacteriome tissue accumulates transcripts from genes involved in cellular development and survival, such as the apoptotic inhibitors iap2 and iap3, and endosomal fusion and trafficking, such as Rab7, Hrs, and SNARE. As regards our investigation into immunity, we first strengthen the bacteriome immunomodulation previously reported in S. zeamais. We show that the sarcotoxin, the c-type lysozyme, and the wpgrp2 genes are downregulated in the S. oryzae bacteriome, when compared to aposymbiotic insects and insects challenged with E. coli. Secondly, transcript level comparison between symbiotic and aposymbiotic larvae provides evidence that the immune systemic response to pathogens is decreased in symbiotic insects, as shown by the relatively high expression of wpgrp2, wpgrp3, coleoptericin-B, diptericin, and sarcotoxin genes in aposymbiotic insects.

Conclusions: Library sequencing significantly increased the number of unigenes, allowing for improved functional and genetic investigations in the cereal weevil S. oryzae. Transcriptomic analyses support selective and local immune gene expression in the bacteriome tissue and uncover cellular pathways that are of potential interest to bacteriocyte survival and homeostasis. Bacterial challenge experiments have revealed that the systemic immune response would be less induced in a symbiotic insect, thus highlighting new perspectives on host immunity in long-term invertebrate co-evolutionary associations.
\end{abstract}

\footnotetext{
* Correspondence: abdelaziz.heddi@insa-lyon.fr

${ }^{1}$ INSA-Lyon, UMR203 BF2I, INRA, Biologie Fonctionnelle Insectes et Interactions, Bat. Louis-Pasteur 20 ave. Albert Einstein, F-69621 Villeurbanne,

France

Full list of author information is available at the end of the article
} 


\section{Background}

Bacterial intracellular symbiosis (endosymbiosis) is widespread in invertebrates and exhibits a large variety of phenotypes, ranging from mutualism to pathogenesis. Endosymbionts are transmitted vertically for hundreds of host generations and affect the host biology in many ways, including reproduction, physiology and behavior [1-4]. The outcome of the association depends on the interactional networks between the host and bacterial partners, which sometimes interfere concomitantly with many cellular features such as metabolism, apoptosis and immunity [5-7].

Insects living on unbalanced nutritional diets house socalled obligate endosymbionts, which interfere in the early stages of host embryogenesis with the differentiation of specialized host cells (the bacteriocytes) that isolate the endosymbionts and protect them from the host immune systemic response $[6,8]$. In addition to the primary endosymbiont, which is fixed in all host populations and is essential for host fitness and survival, insects may integrate, during their evolutionary history, secondary endosymbionts that are facultative and have an impact on other biological and ecological features of the host $[9,10]$. Evidence of symbiont elimination and displacement has also been reported in weevils $[11,12]$ and suspected in other insect groups where multiple bacterial species are coexisting within a single host lineage $[13,14]$.

Once established within the host, endosymbionts can experience severe genome size reduction due to relaxed evolutionary pressures on the genes that are unnecessary or redundant with respect to the host functions [15-17]. As reported in Sodalis, the secondary endosymbiont of the tsetse fly, gene mutation and deletion processes can also affect cell membrane components and genes encoding Microbe-Associated Molecular Patterns (MAMPs) [18]. As these elements are essential for bacterial perception by the host immune system, the complexity of molecular cross-talk between partners may evolve according to the level of bacterial genomic degeneration and, hence, according to the age of the association. However, while physiological and evolutionary aspects of insect endosymbiosis have been thoroughly investigated over the past decades, very little is known about the molecular mechanisms that permit the establishment of symbiosis and then the maintenance and the regulation of symbiotic intracellular bacteria. Important questions concern, first, how endosymbionts are recognized and tolerated by the host immune system, secondly how cellular pathways are regulated to prevent bacteriocyte cell disorders and death due to chronic infection with endosymbionts and, thirdly, how does endosymbiosis influence host immunocompetence directed at pathogens?
In Drosophila melanogaster, microbe recognition leads to signal production via four pathways (Toll, Immune Deficiency (IMD), JNK, and JAK/STAT) [19-21]. Each pathway responds to particular types of pathogens, i.e. Gram-positive bacteria and fungi for Toll and Gramnegative bacteria for IMD. Signalling through the Toll receptor activates a set of phosphorylating reactions involving complex adaptors. An inhibitor protein, called Cactus, is degraded, thus releasing its associated nuclear factor protein, called Dorsal-related Immunity Factor (DIF), which translocates into the nucleus and induces antimicrobial peptide genes. The Imd protein is upstream of two separate pathways. The first pathway involves a protein from the mitogen-activated protein (MAP) 3 kinase family, the dTAK1 (Drosophila transforming growth factor $\beta$ activated kinase 1) associated with dTAB2 (Drosophila TAK1 Binding) [22] and requiring the potential E3 ubiquitin ligase dIAP2 (Drosophila Inhibitor of APoptosis2) [23-25]. The latter appears to be a good candidate for activating the IKK (inhibitor $\mathrm{kB}$ kinase) signalosome proteins, which in turn phosphorylate the Relish (Rel family) transcriptional factor. The second pathway controls the cleavage of Relish. The "Drosophila Fas-associated death-domaincontaining protein" (dFADD), which is homologous to the mammalian adaptor protein that interacts with the complex "tumor necrosis factor receptor 1" (TNF-R1) to recruit pro-caspase-8, links IMD to the caspase "deathrelated ced-3/Nedd2-like" (DREDD) in order to build the "adaptor" complex that allows the activation of caspases and apoptosis [26,27]. This pathway may end with a proteasome-independent proteolytic cleavage of Relish, probably by the DREDD protein [28,29]. The Relish cleavage dissociates the Rel and the Ankyrins and allows for processing of the nuclear transcriptional factor.

To investigate immune and cellular processes in the bacteriome tissue, we have used cereal weevils as a symbiotic system [6,30]. These crop pests include three species (i.e. Sitophilus oryzae, Sitophilus zeamais and Sitophilus granarius) that all have in common an intracellular symbiosis with a Gram-negative $\gamma$-Proteobacterium, called Sitophilus primary endosymbiont (or SPE) [31,32]. Sitophilus insects provide an interesting system for studying host immune responses to symbionts as their association with SPE was established relatively recently (less than $25 \mathrm{MY}$ ago), probably by endosymbiont replacement $[11,12,17]$. The endosymbiont genome has not experienced severe gene deletion [17,33]. It encodes functional secretion systems [34] and genes encoding cell wall elements (unpublished data). Using suppressive subtractive hybridization $(\mathrm{SSH})$, we have already identified several immune-relevant genes of $S$. zeamais species and we have demonstrated that weevil 
bacteriomes exhibit a specific local immune expression that allows symbiont persistence within the bacteriocyte cells [6].

Here, we have studied the sibling S. oryzae species. We have enlarged the panel of genes potentially involved in host-symbiont interaction through the construction and the sequencing of 7 different libraries from whole larvae and from bacteriomes (i.e. SSH, non-normalized and normalized libraries). Bioinformatic analysis of 26,886 ESTs has generated 8,941 unigenes. The results of qRT-PCR experiments strongly support the gene expression profile previously reported for the S. zeamais bacteriome [6], uncover new genes involved in the immune system, apoptosis, vesicular trafficking and cell-growth in the bacteriome tissue, and broaden the proposal that endosymbiosis may influence the host immune response in long-term host-symbiont coevolution.

\section{Methods}

This work has been conducted in parallel with two other invertebrate models (i.e. Armadillidium vulgare/ Wolbachia and Asobara tabida/Wolbachia) with the object of identifying conserved and divergent immune pathways and to determine whether invertebrates have selected common strategies to control their symbionts and to discriminate between symbionts and pathogens $[35,36]$.

\section{Insect manipulation and sample preparation}

Insects used in this study were reared on wheat grains at $27.5^{\circ} \mathrm{C}$ and at $70 \%$ relative humidity (rh). Sitophilus weevils house both the integrated endosymbiont SPE and the facultative endosymbiont Wolbachia [3]. To avoid any side effects from Wolbachia, the "Bouriz" $S$. oryzae strain was chosen because it harbors SPE only. SPE-free aposymbiotic insects were obtained as described previously [37].

Bacteriomes were dissected from fourth instar larvae in Buffer A (25nM KCl, 10nM MgCl2, 250nM Sucrose, $35 \mathrm{nM}$ Tris/ $\mathrm{HCl}, \mathrm{pH}=7.5$ ), and stored at $-80^{\circ} \mathrm{C}$ prior to RNA preparation.

To identify genes involved in the immune response, we challenged fourth instar larvae with the intracellular bacteria Salmonella typhimurium (Salmonella, Strain 12023G). About $10^{5}$ bacteria were injected into the weevil hemolymph, using a Nanoject II apparatus (Drummond, Broomall, PA). The larvae were incubated for 3, 6 or 12 hours at $27.5^{\circ} \mathrm{C}$ and $70 \%$ rh and then stored at $-80^{\circ} \mathrm{C}$ until required for RNA preparation.

\section{Library constructions}

Details of material and conditions used for library constructions are summarized in Table 1.

Total RNA was extracted with TRIzol Reagent (Invitrogen, Cergy-pontoise, France), following the manufacturer's instructions. RNA was purified using the RNeasy mini kit (QIAGEN, Alameda, CA) following the "RNA Clean Up" protocol. After purification, the RNA concentration of each sample was measured with a Nanodrop ${ }^{\circledR}$ spectrophotometer (Thermo Scientific, Wilmington, DE) and total RNA quality was checked by electrophoresis.

Table 1 Libraries description and construction method.

\begin{tabular}{|c|c|c|c|c|c|c|c|}
\hline & Library & Type & Origin & $\begin{array}{c}\text { Status } \\
\text { of } \\
\text { infection }\end{array}$ & $\begin{array}{c}\text { Presence } \\
\text { of } \\
\text { symbiont }\end{array}$ & Description & $\begin{array}{l}\text { Number of individuals / bacteriomes sampled } \\
\text { and pooled (quantity of RNA used from samples) }\end{array}$ \\
\hline \multirow{2}{*}{$\begin{array}{l}\text { Host } \\
\text { response } \\
\text { to } \\
\text { pathogen }\end{array}$} & SSH1 & Subtraction & $\begin{array}{l}\text { Whole } \\
\text { larvae }\end{array}$ & infected & no & Salmonella+ vs. Salmonella- & $\begin{array}{c}\text { Salmonella -: } 10 \text { uninfected aposymbiotic larvae } \\
\qquad(10 \mu \mathrm{g})\end{array}$ \\
\hline & $\mathrm{SSH} 2$ & Subtraction & $\begin{array}{l}\text { Whole } \\
\text { larvae }\end{array}$ & $\begin{array}{c}\text { Not } \\
\text { infected }\end{array}$ & no & Salmonella- vs. Salmonella+ & $\begin{array}{c}\text { Salmonella +: } 15 \text { infected aposymbiotic larvae: } \\
5 \text { collected } 3 \mathrm{~h} \text { after infection }(3.33 \mu \mathrm{g}), 5 \text { after } \\
6 \mathrm{~h}(3.33 \mu \mathrm{g}) \text { and } 5 \text { after } 12 \mathrm{~h}(3.33 \mu \mathrm{g})\end{array}$ \\
\hline \multirow{5}{*}{$\begin{array}{l}\text { Host } \\
\text { response } \\
\text { to } \\
\text { symbiont }\end{array}$} & SSHA & Subtraction & Bacteriome & $\begin{array}{c}\text { Not } \\
\text { infected }\end{array}$ & yes & $\begin{array}{l}\text { With symbiont vs. without } \\
\text { symbiont }\end{array}$ & $\begin{array}{c}\text { With symbiont: } 200 \text { symbiotic bacteriomes (10 } \\
\mu \mathrm{g})\end{array}$ \\
\hline & SSHB & Subtraction & Bacteriome & $\begin{array}{c}\text { Not } \\
\text { infected }\end{array}$ & no & $\begin{array}{l}\text { Without symbiont vs. with } \\
\text { symbiont }\end{array}$ & $\begin{array}{l}\text { Without symbiont: } 640 \text { aposymbiotic } \\
\text { bacteriomes }(10 \mu \mathrm{g})\end{array}$ \\
\hline & SO & $\begin{array}{l}\text { Non- } \\
\text { normalized }\end{array}$ & Bacteriome & $\begin{array}{c}\text { Not } \\
\text { infected }\end{array}$ & yes & $\begin{array}{c}\text { Pool of bacteriomes with } \\
\text { symbiont }\end{array}$ & 170 symbiotic bacteriomes $(10 \mu \mathrm{g})$ \\
\hline & $\mathrm{AO}$ & $\begin{array}{c}\text { Non- } \\
\text { normalized }\end{array}$ & Bacteriome & $\begin{array}{c}\text { Not } \\
\text { infected }\end{array}$ & no & $\begin{array}{c}\text { Pool of bacteriomes without } \\
\text { symbiont }\end{array}$ & 578 aposymbiotic bacteriomes $(10 \mu \mathrm{g})$ \\
\hline & NOR & Normalized & $\begin{array}{l}\text { Whole } \\
\text { larvae }\end{array}$ & infected & yes & $\begin{array}{l}\text { Pool of Symbiotic Larvae / } \\
\text { Aposymbiotic larvae / } \\
\text { Aposymbiotic larvae infected } \\
\text { during } 3 \mathrm{~h}, 6 \mathrm{~h} \text { and } 12 \mathrm{~h}\end{array}$ & $\begin{array}{c}10 \text { uninfected aposymbiotic larvae }(2 \mu \mathrm{g}) / 10 \\
\text { uninfected symbiotic larvae }(2 \mu \mathrm{g}) / 15 \text { infected } \\
\text { aposymbiotic larvae: } 5 \text { collected after } 3 \mathrm{~h} \text { of } \\
\text { infection }(2 \mu \mathrm{g}), 5 \text { after } 6 \mathrm{~h}(2 \mu \mathrm{g}) \text { and } 5 \text { after } 12 \mathrm{~h} \\
(2 \mu \mathrm{g})\end{array}$ \\
\hline
\end{tabular}




\section{Libraries prepared from bacteriome tissue}

SO (symbiont-full bacteriome) and AO (symbiont-free bacteriome) Libraries (see Table 1) were prepared using the Creator SMART cDNA Library Construction kit (Clontech/BD Biosciences, PaloAlto, CA), following the manufacturer's instructions. cDNA was digested with Sfil, purified (BD Chroma Spin - 400 column) and then ligated into a pDNRlib vector for $E$. coli transformation. SSH

SSHA (symbiont-full/symbiont-free bacteriome), SSHB (symbiont-free/symbiont-full bacteriome), SSH1 (Challenged/Non-Challenged with S. typhimurium) and SSH2 (Non-Challenged/Challenged with S. typhimurium) were performed by Evrogen (Moscow, Russia). In order to reduce the number of false-positive clones in the SSHgenerated libraries, the SSH technology was combined with a mirror orientation selection procedure [38]. Purified cDNA were cloned into the pAL16 vector (Evrogen, Moscow, Russia) and used for E. coli transformation.

\section{Normalized library}

NOR was prepared by Evrogen (Moscow, Russia). Total RNA was used for ds cDNA synthesis using the SMART approach [39]. SMART prepared amplified cDNA was then normalized according to [40]. Normalization included cDNA denaturation and reassociation, using treatment with duplex specific nuclease (DSN), as described by [41]. Normalized cDNA was purified using a QIAquick PCR Purification Kit (QIAGEN, Alameda, CA), digested with restriction enzyme Sfi1, purified (BD Chroma Spin - 1000 column), and ligated into a pAL 17.3 vector (Evrogen, Moscow, Russia) for E. coli transformation.

\section{EST sequencing and data processing}

All clones from the libraries were sequenced using the Sanger method (Genoscope, Evry, France) and were deposited in the GenBank database. A general overview of the EST sequence data processing is given in Figure 1. Raw sequences and trace files were processed with Phred software $[42,43]$ in order to remove any low quality sequences (score $<20$ ). Sequence trimming, which includes polyA tails/vector/adapter removal, was performed by cross_match. Chimerical sequences were computationally digested into independent ESTs.

Clustering and assembly of the ESTs were performed with TGICL [44] to obtain unique transcripts (unigenes) composed of contiguous ESTs (contigs) and unique ESTs (singletons). For this purpose, a pairwise comparison was first performed using a modified version of megablast (minimum similarity 94\%). Clustering was

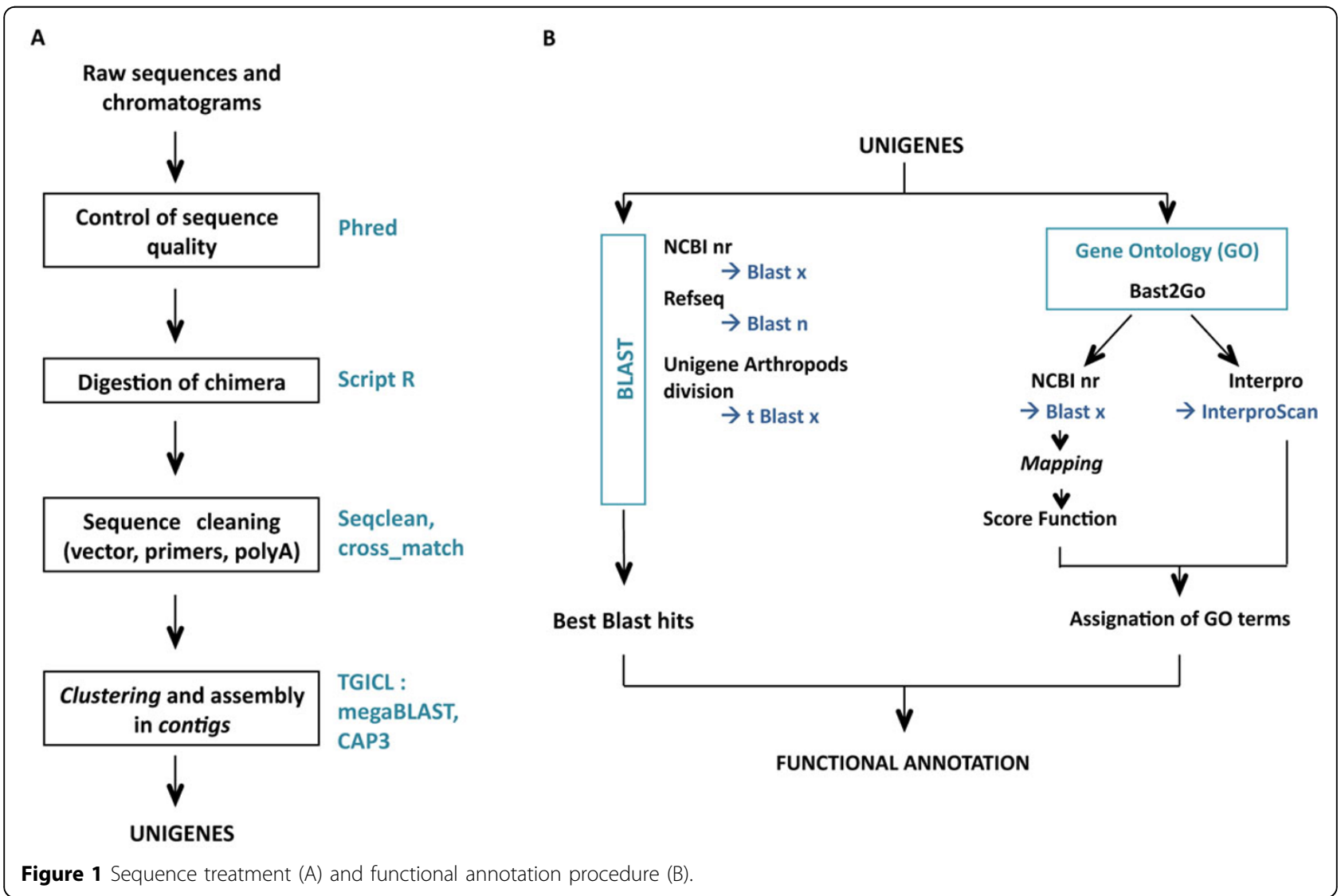


performed with tclust, that works via a transitive approach (minimum overlap: $60 \mathrm{bp}$ to $20 \mathrm{bp}$ maximum from the end of the sequence). Assembling was carried out with CAP3 (minimum similarity 94\%).

To detect unigene similarities with other species, several blasts (with high cut-off e-values) were performed against the following databases: NCBI nr (blastx (release: 1 March 2011); e-value < 5, HSP length > 33aa), Refseq genomic database (blastn, e-value $<10$ ), Unigene division Arthropods (tblastx, \#8 Aedes aegypti, \#37 Anopheles gambiae, \#3 Apis mellifera, \#3 Bombyx mori, \#53 Drosophila melanogaster, \#9 Tribolium castaneum; evalue $<5)$. Gene Ontology annotation was carried out using blast2go software [45]. In the first step (mapping), a pool of candidate GO terms was obtained for each unigene by retrieving GO terms associated with the hits obtained after a blastx search against NCBI nr. In the second step (annotation), reliable GO terms were selected from the pool of candidate GO terms by applying the Score Function (FS) of Blast2go with 'permissive annotation' parameters (EC-weight $=1$, e-value-filter $=0.1$, GO-weight $=5, \mathrm{HSP} /$ hit coverage cut-off $=0 \%$ ). In the third step of the annotation procedure, the pool of GO terms selected during the annotation step was merged with GO terms associated with the Interpro domain (InterproScan predictions based on the longest ORF). Finally, the Annex augmentation step was run to modulate the annotation by adding GO terms derived from implicit relationships between GO terms [46].

\section{Statistical analyses on libraries}

We have used the randomization procedure (with 500 random datasets) and the $\mathrm{R}$ statistic, described in [47], to detect unigenes whose transcript abundance (number of ESTs) in symbiont-free and symbiont-full bacteriome libraries was statistically different (at a FDR of 5.5\%). In order to perform a functional enrichment analysis of the unigenes extracted from the $\mathrm{SSH}$, we used the Fatigo web tool [48] against the SO library.

\section{Transcriptomic study}

\section{Sample preparation}

Transcriptomic analysis was performed on larval bacteriomes, whole symbiotic and aposymbiotic larvae, nontreated, mock-infected (injected with PBS), and injected with $10^{5}$ E. coli (TOP10, Invitrogen, Cergy-pontoise, France). The E. coli bacterium was used here because it has been shown to efficiently induce the weevil immune system [6], and this bacterium does not necessitate an L2 safety lab structure for manipulation. Larvae were then maintained at $27.5^{\circ} \mathrm{C}$ and $70 \%$ rh for 6 hours. For each modality, 5 samples of 5 pooled larvae were prepared and then frozen at $-80^{\circ} \mathrm{C}$. Bacteriomes were dissected from non-treated larvae that have been maintained at $27.5^{\circ} \mathrm{C}$ and $70 \%$ rh for 6 hours. 5 samples of 25 pooled bacteriomes were dissected and then frozen at $-80^{\circ} \mathrm{C}$ until RNA extraction.

\section{Total RNA extraction and CDNA synthesis}

Total RNA from whole larvae was extracted with the TRIzol Reagent (Invitrogen, Cergy-pontoise, France), following the manufacturer's instructions. RNA was incubated with $1 \mathrm{U} / \mathrm{g}$ of RQ1 RNase-Free DNase (Promega, Charbonnières-les-Bains, France) for $30 \mathrm{~min}$, at $37^{\circ} \mathrm{C}$. Total RNA from bacteriomes was extracted with RNAqueous ${ }^{\circledR}$-Micro (Ambion, Applied Biosystems, Austin, TX), which allows for a better RNA yield from small tissue samples. After purification, the RNA concentration was measured with a Nanodrop ${ }^{\circledR}$ spectrophotometer (Thermo Scientific, Wilmington, DE) and the RNA quality was checked on an agarose gel electrophoresis. Reverse-transcription into the first cDNA strand was carried out using the First strand Synthesis System for the RT-PCR kit (Invitrogen, Cergy-pontoise, France).

\section{Real-time RT PCR transcript quantification}

Quantitative measurements were performed on RNA samples originating from 5 independent replicates. Quantification was performed with a LightCycler ${ }^{\circledR} 480$ system using the LightCycler Fast Start DNA Master SYBR green I kit (Roche Diagnostics, Meylan, France). Data were normalized using the ratio of the target cDNA concentration to that of the glyceraldehyde 3phosphate dehydrogenase (gapdh) gene and the ribosomal protein L29 (RPL29) gene. Primers were designed to amplify fragments with less than $250 \mathrm{bp}$ and are listed in the additional file 1.

The PCR reactions were carried out in LightCycler 96well plates, in a final volume of $10 \mu \mathrm{l}$, containing $2.5 \mu \mathrm{l}$ of cDNA samples (diluted five-fold) and $7.5 \mu \mathrm{l}$ of Light Cycler $^{(B)} 480$ SYBR Green Master 1 mix, together with $0.5 \mu \mathrm{l}$ of $10 \mathrm{mM}$ of each primer, $1.5 \mu \mathrm{l} \mathrm{H} 2 \mathrm{O}$ and $5 \mu \mathrm{l}$ of Mastermix. Quantification was realized as described by [49]. Normalization and statistical pair-wise comparisons were determined using REST [50]. When comparing more than two modalities at the same time, the nonparametric Kruskal-Wallis test was used. RPL29 was shown to be the best housekeeping gene, with Bestkeeper tool [51], and this has been used in graphical representations.

\section{Results}

\section{General characteristics of libraries: 8,941 weevil unigenes} were generated

To explore bacteriome cellular specificities and weevil immune responses to bacteria, we have constructed 7 cDNA libraries from S. oryzae larvae. These libraries comprise the 4 SSH libraries, SSHA, SSHB, SSH1 and $\mathrm{SSH} 2$, the 2 non-normalized libraries from symbiont-full (SO) and symbiont-free ( $\mathrm{AO})$ bacteriomes and one 
normalized library (NOR) from whole aposymbiotic larvae challenged, and not, with S. typhimurium (Fig. 2A).

The sequencing of all the libraries has generated 26,886 readable ESTs with sequence mean lengths of $520 \pm 177 \mathrm{bp}$. Contigation analysis has generated 8,941 unigenes. The average length of unigenes was $620 \pm 260$ $\mathrm{bp}$, which suggests that most of the unigenes were obtained from low contigation of ESTs. Indeed, the analysis of unigene compositions in ESTs showed that about $88 \%$ of unigenes were obtained from between one (singleton) to four ESTs and less than 3.5\% of unigenes were assembled from more than 10 ESTs (Fig. 2B). This finding highlights a low quantitative sequencing depth with the Sanger methodology and advocates next-generation sequencing (NGS) methods, such as Illumina, to fulfill in silico quantitative analysis of this work. The GC content of total sequences is about $35 \%$, which is very close to the genomic GC content of Tribolium castaneum (34\%), phylogenetically the closest Coleopteran species sequenced so far [52]. Sequences covered around $5.5 \mathrm{Mb}$ against $14 \mathrm{Mb}$ of predicted transcripts in Drosophila.
The distribution of unigenes in the different libraries is presented in Figure 2A. More than $60 \%$ of the unigenes were provided by the NOR library, showing the importance of normalization for unigene number enrichment. Blast analysis has shown that most of the first hits were from Tribolium castaneum sequences. This result was as expected and is linked with the relatively high phylogenetic proximity between Tribolium and Sitophilus.

Only about $25 \%$ of the unigenes had no Blast annotation that corresponded to the UTR part of the cDNA. Following the Blast2go annotation procedure for High Scoring Pair (HSP) coverage of 0\%, 3845 unigenes presented at least one GO term (Fig. 2C). After Interproscan prediction and the Annex procedure, 3995 unigenes presented at least one GO term association.

\section{Analysis of libraries}

One of the objects of this study was to unravel the genes involved in host-symbiont interactions within the bacteriome. For this purpose, an in silico subtraction was conducted between SO and AO libraries, which

\begin{tabular}{|c|c|c|c|c|c|}
\hline Library & Number of ESTs & Number of Unigenes & $\begin{array}{l}\text { Percentage of } \\
\text { total Unigenes }\end{array}$ & $\begin{array}{l}\text { Percentage of } \\
\text { mitochondrial } \\
\text { sequences }\end{array}$ & $\begin{array}{l}\text { Percentage of } \\
\text { rRNA sequences }\end{array}$ \\
\hline $\mathrm{SSH} 1$ & 689 & 267 & 2.8 & 0.7 & 1.2 \\
\hline $\mathrm{SSH} 2$ & 697 & 199 & 2.1 & 5.5 & 1.1 \\
\hline so & 3335 & 758 & 7.2 & 10 & 0.9 \\
\hline AO & 4180 & 1721 & 16.3 & 5.8 & 1.9 \\
\hline SSHA & 703 & 139 & 1.3 & 0.1 & 2 \\
\hline SSHB & 844 & 299 & 3.2 & 0.5 & 1.3 \\
\hline NOR & 16438 & 7221 & 67 & 1.6 & 0.1 \\
\hline
\end{tabular}

B

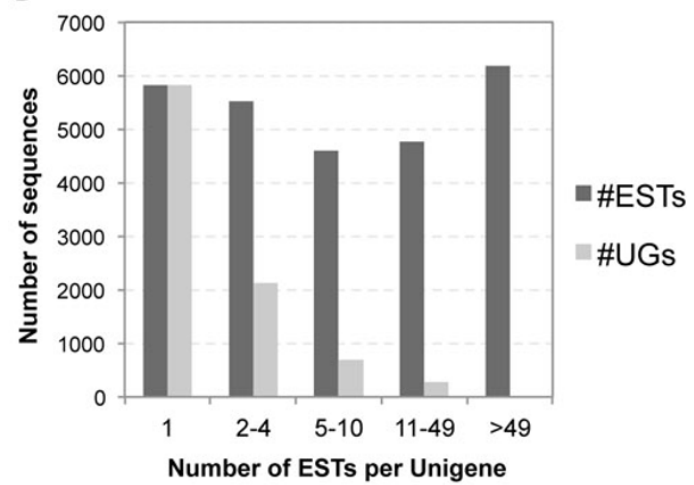

C

\begin{tabular}{cccc} 
Procedure & FS & FS+IPR & FS+IPR+ANNEX \\
\hline No hit & 1977 & 1977 & 1977 \\
No mapping & 2385 & 2264 & 2264 \\
No annotation & 724 & 711 & 711 \\
Annotation & $\mathbf{3 8 4 5}$ & $\mathbf{3 9 9 5}$ & $\mathbf{3 9 9 5}$ \\
\hline
\end{tabular}

Figure 2 General description of libraries. (A) Table of ESTs and Unigene numbers presented for each library. The percentages of mitochondrial and rRNA sequences are also provided. (B) Distribution of unigenes (UGs) as a function of the number of ESTs involved in the UG sequences. UGs with only one EST are singletons, UGs with more than one EST are contigs. (C) Blast2go annotation results. Number of sequences presenting GO terms association is given for each step of the functional annotation. The different steps are described in the Methods section. 
evaluates statistical differences in unigenes prevalence in the presence or absence of the symbiont in the bacteriome tissue. This analysis identified 11 differentially expressed genes (Table 2). The most differentially expressed gene showed the first blastx hit with a cellular Fatty-acid binding protein (FABP), and presented a calycin domain with the Interproscan tool. It is predicted that it would be upregulated in the presence of SPE. However, this first blastx hit presented a relative low evalue (i.e. 6e-05) and the predicted protein of the sequence showed a weak similarity with the fatty-acid protein (32\% on 132 predicted amino acids). This finding highlights the need for additional work to clarify the annotation of this gene. As this gene was also reported as being the most highly expressed in the bacteriome of $S$. zeamais [30], it is referred to as the "Most Expressed Gene in the weevil Bacteriome" (MEGwB).

The subtraction has also identified two other sequences, which are highly expressed in the symbiontfull bacteriome, when compared to the symbiont-free bacteriome. The first was related to methylmalonyl-CoA decarboxylase (58\% similarity based on predicted protein) and the second was a transmembrane protein close to the Tribolium transmembrane $41 \mathrm{~B}$ protein. On the other hand, 4 sequences related to the cathepsin 1-like protein, the chemosensory protein, the ribosomal protein L37 and the myoinositol oxygenase, all showed significantly higher expression in the symbiont-free bacteriome. Finally, it is noteworthy that 4 sequences, including 2 more expressed in the symbiont-full bacteriome and 2 more expressed in the symbiont-free bacteriome, have neither Blast annotation nor an Interproscan definition domain. Such sequences cannot be used in this state and require further characterization.

In addition to in silico subtraction, SSHA and SSHB libraries were also constructed with the aim of identifying genes involved in host-symbiont interactions. As described in the Methods section, we carried out a functional enrichment analysis of SSHA and SSHB in order to highlight major GO terms associated with these library sequences (see Additional file 2). Concerning the SSHA library, three GO terms from biological processes (i.e. "transposition", "cell division", "DNA recombination") and one GO term from molecular functions (i.e. "transposase activity") were significantly over-represented. Concerning SSHB, five GO terms from biological processes (i.e. "digestion", "nitrogen compound metabolic process", "carbohydrate metabolic process",

Table 2 List of unigenes presenting statistically different representations in AO and SO libraries.

\begin{tabular}{|c|c|c|c|c|c|c|c|c|c|c|}
\hline $\begin{array}{l}\text { Accession } \\
\text { numbers }\end{array}$ & ${ }^{1} R$ & $\begin{array}{l}\text { Unigene } \\
\text { length } \\
(p b)\end{array}$ & $\begin{array}{l}{ }^{2} \text { Redundancy } \\
\text { in } A O\end{array}$ & $\begin{array}{l}{ }^{2} \text { Redundancy } \\
\text { in SO }\end{array}$ & $\begin{array}{l}\text { 31st blastx result on } \\
\text { Tribolium Castaneum }\end{array}$ & ${ }^{3}$ Accession & ${ }^{3}$ e-value & ${ }^{3}$ Coverage & $\begin{array}{l}{ }^{3} \text { Max } \\
\text { identity }\end{array}$ & $\begin{array}{l}{ }^{4} \text { InterProScan } \\
\text { predicted domain }\end{array}$ \\
\hline FQ866673 & 16.45 & 664 & 24 & 103 & $\begin{array}{l}\text { allergen aca S13 } \\
\text { (cellular FABP-like) }\end{array}$ & XP_969762 & $6 e-05$ & $50 \%$ & $32 \%$ & $\begin{array}{l}\text { IPR011038; } \\
\text { IPR012674 }\end{array}$ \\
\hline $\begin{array}{l}\text { FQ866935, } \\
\text { FQ867818 }\end{array}$ & 15.91 & 1307 & 304 & 440 & NA & NA & NA & NA & NA & no IPR \\
\hline FQ877624 & 5.21 & 723 & 21 & 0 & NA & NA & NA & NA & NA & No IPR \\
\hline FQ884311 & 3.22 & 351 & 13 & 0 & RPL37 & XP_969650 & $3 e-36$ & $76 \%$ & $94 \%$ & $\begin{array}{l}\text { IPR001569; } \\
\text { IPR011331; } \\
\text { IPR011332; } \\
\text { IPR018267 }\end{array}$ \\
\hline FQ868370 & 2.9 & 525 & 17 & 1 & $\begin{array}{l}\text { Chemosensory } \\
\text { protein } 10\end{array}$ & NP_001039278 & $6 e-33$ & $75 \%$ & $49 \%$ & IPR005055 \\
\hline FQ862292 & 2.9 & 974 & 17 & 1 & $\begin{array}{l}\text { Cathepsin L-like } \\
\text { proteinase }\end{array}$ & NP_001163996 & $2 e-68$ & $88 \%$ & $48 \%$ & no IPR \\
\hline FQ869260 & 2.73 & 138 & 11 & 0 & NA & NA & NA & NA & NA & No IPR \\
\hline FQ865010 & 2.49 & 865 & 12 & 28 & $\begin{array}{l}\text { Gamma-subunit. } \\
\text { methylmalonyl-CoA } \\
\text { decarboxylase }\end{array}$ & XP_973308 & $2 \mathrm{e}-24$ & $54 \%$ & $58 \%$ & IPR010625 \\
\hline $\begin{array}{l}\text { FQ884611, } \\
\text { FQ867701 }\end{array}$ & 2.48 & 1463 & 10 & 0 & $\begin{array}{l}\text { Myoinositol } \\
\text { oxygenase }\end{array}$ & XP_966469 & $3 e-133$ & $6 \%$ & $74 \%$ & IPR007828 \\
\hline FQ864415 & 2.17 & 704 & 0 & 6 & $\begin{array}{l}\text { Transmembrane } \\
\text { protein } 41 \mathrm{~B}\end{array}$ & XP_975236 & $1.8 \mathrm{e}-02$ & $25 \%$ & $42 \%$ & No IPR \\
\hline FQ863216 & 2.17 & 812 & 0 & 6 & NA & NA & NA & NA & NA & no IPR \\
\hline
\end{tabular}

${ }^{1}$ The R statistic test, with 500 random datasets, was performed to evaluate genes whose representation in AO and SO libraries was statistically different. Sequences showing an $\mathrm{R}$ statistic $>2$ were significant.

${ }^{2}$ Unigene redundancy is given for each library (AO and SO).

${ }^{3}$ For each unigene, we gave blastx matches with Tribolium castaneum, the closest genome-sequenced insect, phylogenetically, to Sitophilus. Accession numbers of Tribolium related sequences, e-value of blastx hits, sequences coverage and max identity between Sitophilus and Tribolium sequences are also given.

${ }^{4}$ Interproscan predicted domains are given to complete the characterization of sequences. 
"polysaccharide metabolic process", and "energy derivation by oxidation of organic compounds") and nine GO terms from molecular functions (i.e. "hydrolase activity", "ion binding", "tetrapyrole binding", "hydrolase activity, acting on glycosyl bonds", "monooxygenase activity", "peptidase activity", "heme binding", "cation binding" and "hydrolase activity, hydrolyzing O-glycosyl compounds") were significantly over-expressed.

The SSHA yielded 55 unigenes with the eukaryotic blast result. A detailed listing of these unigenes is presented in Additional file 3. The remaining unigenes were related to prokaryotic assignation, which means that the subtraction has been contaminated with symbiont DNA. Surprisingly, none of the 55 unigenes were related to the immune response and only one, an aspartic proteinase, presented a high similarity $(96 \%)$ with a sequence found in S. zeamais [6]. Most of the SSHA unigenes are referred to as metabolic or cellular regulation genes, suggesting high cellular activity in the symbiont-full bacteriome [30]. The functional enrichment analysis has allocated, to the SSHA, the level $3 \mathrm{GO}$ terms "transposition" (GO:0032196) and "transposase activity" (GO:0004803). This is probably due to the massive presence of insertion sequences (IS) recently documented in the SPE genome [17].

The 844 EST sequences from SSHB have provided 299 unigenes potentially expressed specifically in the symbiont-free bacteriome. Blastx annotations have identified around $60 \%$ of these sequences as digestive enzymes. Functional analysis of SSHB has allocated the level 3 GO terms, such as "digestion" (GO:0007586), "nitrogen compound metabolic process" (GO:0006807) or "hydrolase activity" (GO:0016787). As these functions are dominant in the gut tissue, and as symbiont-free bacteriomes are very thin, flat and intimately attached to the intestine, contamination from the gut is highly probable while dissecting out the bacteriomes.

\section{Transcriptomic study}

The purpose of the transcriptomic study was to analyze molecular and cellular specificities of the bacteriome and to test the influence of symbiosis on the host immune response to bacterial pathogens. Analyzed genes were retrieved from different libraries based on in silico subtraction, experimental subtractions ( $\mathrm{SO}, \mathrm{AO}$, SSHA), and on the examination of genes involved in cellular pathways of potential interest to intracellular symbiosis, such as apoptosis, cell trafficking and immunity (NOR, SSH1).

In total, we have selected 29 genes (Additional file 4). Except for MEGwB, all sequences presented more than $60 \%$ similarity with their first hit on the blastx and/or major Interproscan domains of the unigene predicted protein.

\section{Differential gene expression in the bacteriome tissue}

We have compared the steady state levels of 29 genes in the bacteriome and in the whole aposymbiotic larvae (Fig. 3). We preferred to use whole aposymbiotic larvae, rather than symbiont-free bacteriome tissue, as the control because SSHB is prone to a lot of potential contamination from the gut. The total transcriptome of larvae represented an average level of gene transcripts and this was then used as the control.

As described previously in S. zeamais [6], only Toll Interacting Protein (TollIP), as a potential negative regulator of the vertebrate Toll pathway [53] and coleoptericin-A, as AMP, are upregulated in the bacteriome of $S$. oryzae. The sarcotoxin and genes described as having lytic activity, such as wpgrp2 (weevil PeptidoGlycan Recognition Protein2), gnbp1 (Gram Negative Binding Protein1) and c-type lysozyme, are significantly downregulated in the bacteriome when compared to aposymbiotic larvae challenged, or not, with E. coli (Fig. 3 and 4).

To gain a better understanding of immune regulation in the bacteriome, we have analyzed additional genes identified in this work, which are branched at different levels of the signaling pathways, including imd and iap2 (IMD pathway), and cactus and ecsit (Toll pathway) [23,54-56]. Intriguingly, the imd and iap 2 genes, which activate AMP synthesis via the IMD pathway in Drosophila, are highly expressed in the Sitophilus bacteriome. Moreover, the ecsit gene, which participates in Toll-signaling pathway activation in vertebrates [56,57], is also highly expressed in the bacteriome whereas the Toll inhibitor cactus is downregulated (Fig. 3). Taken together, these data suggest that both IMD and Toll pathways are potentially initiated in the bacteriome, which appears to be in contrast with the low amounts of effector gene transcripts (e.g. AMP) in this tissue.

To extend this investigation to other cellular processes that are of interest to bacteriocyte homeostasis and survival, we have analyzed three genes potentially involved in apoptosis activation and regulation, namely the Inhibitor of APoptosis2 (iap2), the Inhibitor of APoptosis3 (iap3), and the caspase-like gene. Whilst apoptosis inhibitor genes (i.e. iap 2 and iap3) are highly expressed, the caspase-like encoding gene is weakly expressed in the bacteriome (Fig. 3 and 4). In line with this finding, the RAt Sarcoma (Ras), calmodulin-1 and leonardo 14-3-3, which are all involved in cell growth and survival [58-60], are also upregulated in the bacteriome. Taken together, these data suggest that bacteriocyte cell pathways are regulated to prevent cell death and to promote cell survival.

Vesicular trafficking is also an important process in the bacteriocyte functions, both for metabolic exchange between the host and the endosymbiont [30] 


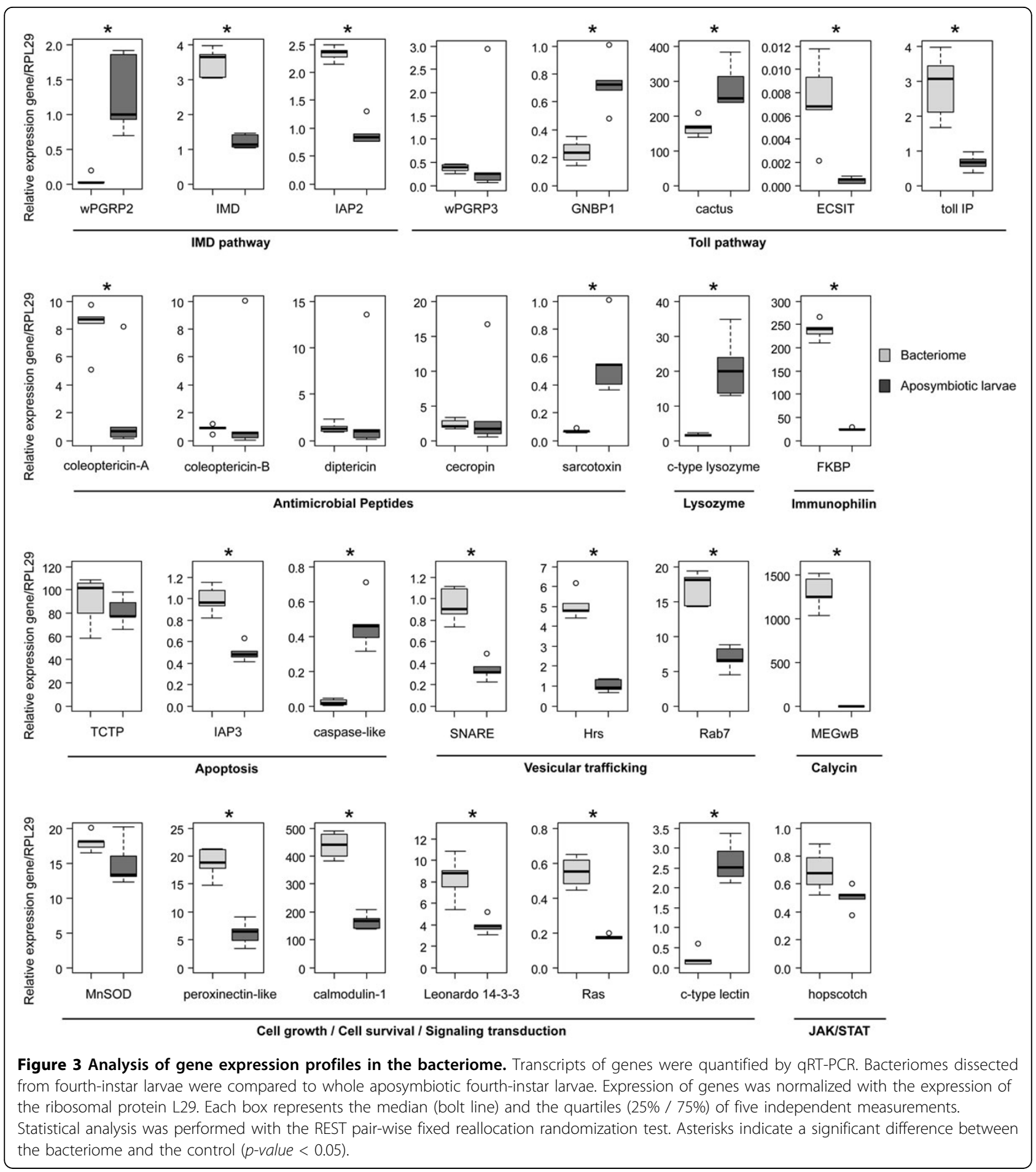

and for intracellular bacterial control by cellular autophagy [61]. Among the selected genes, we have tested three genes involved in vesicular formation and trafficking, these being the Ras related GTP-binding gene (Rab7, late endosomes labelling), the hepatocyte growth factor-regulated tyrosine kinase substrate (Hrs, involved in endosomal maturation) and a gene encoding for a Soluble NSF Attachment protein REceptor (SNARE, vesicle fusion) [62-64]. We have demonstrated that all these genes are highly expressed in the bacteriome, when compared to the aposymbiotic larvae (Fig. 3). 

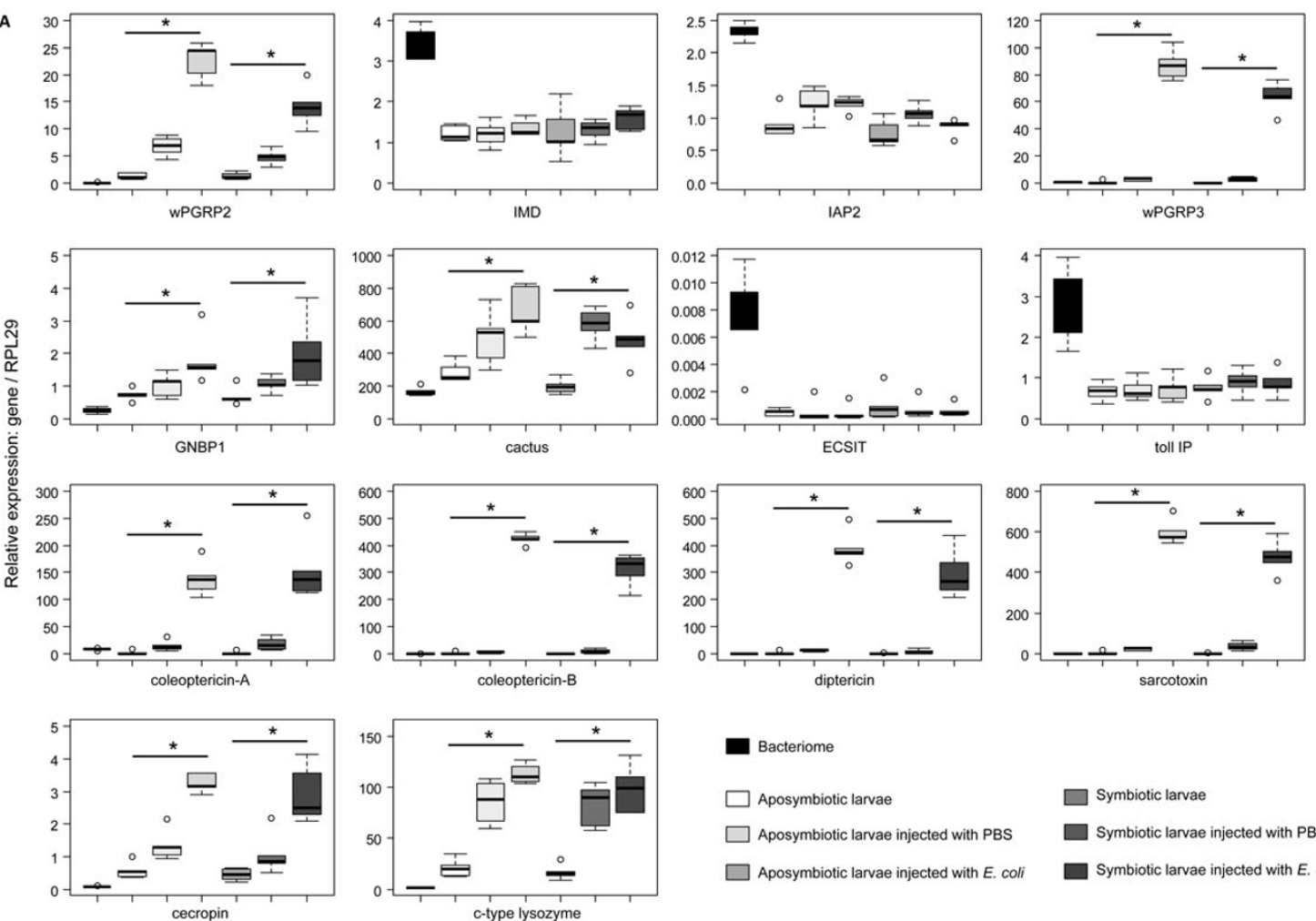

Bacteriom

$\square$ Aposymbiotic larvae

$\square$ Aposymbiotic larvae injected with PBS

$\square$ Aposymbiotic larvae injected with E. coli
Symbiotic larvae

Symbiotic larvae injected with PBS

Symbiotic larvae injected with $E$. coli

Impact of symbiosis on genes expression

Relative ratio of genes expression: (Symbiotic larvae) / (Aposymbiotic larvae)

B

\begin{tabular}{l|cccc} 
& & \multicolumn{2}{c}{$\begin{array}{c}\text { Relative ratio of genes expression: } \\
\text { (Larvae injected with PBS) / (Larvae not injected) }\end{array}$} & \multicolumn{2}{c}{$\begin{array}{c}\text { Relative ratio of genes expression: } \\
\text { (Larvae injected with } E \text {. coli) / (Larvae injected with PBS) }\end{array}$} \\
\cline { 3 - 5 } & Aposymbiotic larvae & Symbiotic larvae & Aposymbiotic larvae & Symbiotic larvae \\
\hline & wPGRP2 & $\underline{5.33} \uparrow$ & $\underline{3.63} \uparrow$ & $\underline{3.32} \uparrow$
\end{tabular}

\begin{tabular}{|c|c|c|c|c|c|c|c|c|}
\hline \multirow{3}{*}{$\begin{array}{l}\text { IMD } \\
\text { pathway }\end{array}$} & wPGRP2 & $\underline{5.33} \uparrow$ & $\underline{3.63} \uparrow$ & $\underline{3.32} \uparrow$ & $\underline{2.97} \uparrow$ & 1.03 & 0.7 & $\underline{0.63}$. \\
\hline & IMD & - & - & - & - & 1.04 & 1.08 & 1.17 \\
\hline & IAP2 & - & - & - & - & 0.84 & 0.87 & $\underline{0.71}$ \\
\hline \multirow{5}{*}{$\begin{array}{c}\text { Toll } \\
\text { pathway }\end{array}$} & wPGRP3 & $4.00 \uparrow \uparrow$ & $\underline{7.13} \uparrow$ & $\underline{29.73} \uparrow$ & $\underline{21.89} \uparrow$ & 0.56 & 0.99 & $\underline{0.73}$ \\
\hline & GNBP1 & 1.39 & 1.56 & $\underline{1.80} \uparrow$ & $\underline{1.90} \uparrow$ & 0.93 & 1.04 & 1.1 \\
\hline & cactus & $\underline{1.74} \uparrow$ & $\underline{2.94} \uparrow$ & 1.34 & 0.83 & 0.69 & 1.17 & 0.73 \\
\hline & ECSIT & - & - & - & - & 2.1 & 1.34 & 1.46 \\
\hline & Toll IP & - & - & - & - & 1.15 & 1.26 & 1.18 \\
\hline \multirow{5}{*}{ AMPs } & coleoptericin-A & $\underline{7.08} \uparrow$ & $\underline{10.36} \uparrow$ & $\underline{\underline{9.57}} \uparrow$ & $\underline{8.28} \uparrow$ & $\underline{0.88}$ & 1.29 & 1.11 \\
\hline & coleoptericin-B & $\underline{2.30} \uparrow$ & $\underline{31.55} \uparrow$ & $\underline{80.40} \uparrow$ & $\underline{34.62} \uparrow$ & 0.12 & 1.7 & $\underline{0.73}$. \\
\hline & diptericin & $\underline{3.48} \uparrow$ & $\underline{14.72} \uparrow$ & $\underline{34.54} \uparrow$ & $\underline{35.39} \uparrow$ & 0.18 & 0.74 & $\underline{0.76}$ \\
\hline & cecropin & $\underline{2.36} \uparrow$ & $\underline{2.37} \uparrow$ & $\underline{2.98} \uparrow$ & $\underline{2.73} \uparrow$ & 0.78 & 0.79 & 0.73 \\
\hline & sarcotoxin & $\underline{5.42} \uparrow$ & $\underline{22.20} \uparrow$ & $\underline{24.22} \uparrow$ & $\underline{12.75} \uparrow$ & 0.37 & 1.51 & $\underline{0.79}$ \\
\hline Lysozyme & c-type lysozyme & $\underline{4.06} \uparrow$ & $4.93 \uparrow$ & $1.33 \uparrow$ & 1.19 & 0.79 & 0.97 & 0.87 \\
\hline
\end{tabular}

Figure 4 Quantitative immune gene expression in symbiotic and aposymbiotic larvae of Sitophilus oryzae. (A) Transcript levels of immune genes quantified by qRT-PCR in whole aposymbiotic and symbiotic larvae. For both symbiotic and aposymbiotic larvae, non-injected larvae, larvae injected with PBS, and larvae injected with E. coli were analyzed. Results from gene expression in the bacteriome are reported here as an indicator. Represented expression of genes was normalized with the expression of the ribosomal protein L29. Each box represents the median (bolt line) and quartiles (25\% / 75\%) of five independent measurements. For each symbiotic and aposymbiotic status, the nonparametric Kruskal-Wallis test was applied in order to determine global difference between the three modalities tested $(p$-value $<0.05)$, represented by an asterisk. (B) Differential expression ratios obtained from q-RT-PCR experiments. For genes presenting significant differences in expression after the global test (see A), the pricking stress effect was tested by comparing larvae injected, or not, with PBS. The infection effect was tested by comparing larvae injected with PBS and larvae injected with E. coli. The REST pair-wise fixed reallocation randomization test was applied. For each modality tested (not injected, injected with PBS and injected with E. coli), a comparison between symbiotic larvae and aposymbiotic larvae was applied in order to evaluate the impact of symbiosis on the expression of immune genes. The REST pair-wise fixed reallocation randomization test was performed between the expression of genes from symbiotic and aposymbiotic larvae. Underlined scores indicate significant differences between the two modalities tested ( $p$-value $<0.05)$. An up-arrow indicates upregulated genes whereas a downarrow indicates downregulated genes. 
Finally, the most highly represented gene transcript in the bacteriome is MEGwB (more than 1500 fold, compared to aposymbiotic larvae). While this high expression suggests an important role for this gene in relation to symbiosis, bioinformatic analysis did not, unfortunately, determine precisely the function of this gene. Nevertheless, the MEGwB sequence includes a calycin domain that characterizes lipocalins and FABP genes. Lipocalins have been shown to be modulators of the immune response in vertebrates [65,66], and an FABP protein has been seen to be active in cell proliferation caused by tumors [67].

\section{Influence of symbiosis on host immune gene expression}

In order to test whether the insect immune response to bacterial pathogens is influenced by symbiosis, we have compared immune gene expression between symbiotic and aposymbiotic larvae. We have analyzed both larval responses to pricking stress (PBS injection) and to the challenge of the Gram-negative bacterium, E. coli (Fig. 4).

Both symbiotic and aposymbiotic larvae were shown to respond slightly, but significantly, to an injection of PBS in the hemolymph. Induced genes included wpgrp2, wpgrp3, gnbp 1, cactus, c-type lysozyme and all AMPs. When larvae were challenged with $E$. coli, all of these genes (except cactus and c-type lysozyme) were highly induced, when compared with the mock-infected larvae.

Concerning the impact of symbiosis on immune response efficiency, the stress generated by PBS injection did not induce any significant difference between symbiotic and aposymbiotic larvae at the transcriptional level for all the genes studied. However, following infection with $E$. coli, aposymbiotic larvae displayed a higher expression of immune gene, when compared with symbiotic larvae (Fig. 4). Among the genes studied, wpgrp2, wpgrp3, the coleoptericin- $\mathrm{B}$, the sarcotoxin and the diptericin were all significantly less induced in symbiotic insects than in aposymbiotic ones.

\section{Discussion and conclusion}

The last decade has seen a growing number of projects investigating the molecular and cellular interactions between invertebrate hosts and their symbionts [5-7,30,68-73]. These have focused on the immune (and bacterial) adaptive changes that favor the establishment of symbiosis $[18,70]$, the maintenance and control of symbiosis $[6,72,74,76]$, and the impacts of symbiosis on host immunocompetence and fitness benefit [9,77-82]. While recent data have provided original and exciting insights in these fields, much more effort needs to be deployed on the molecular and genetic aspects of additional invertebrate systems to unravel the conserved and diverged mechanisms in host-symbiont interactions. With this aim, we have first enlarged the gene repertoire of the cereal weevil S. oryzae and, secondly, we have used qRT-PCR to examine the expression of a set of genes in different conditions, taking into consideration the bacteriocyte molecular basis and symbiont impacts on the host immune response.

Bioinformatic analyses of 26,886 EST sequences, from different libraries, have generated 8,941 unigenes. This gene repertoire, along with the recent effective application of RNA interference (RNAi) technology in Sitophilus [49], will enable us to carry out more functional studies and to decipher cellular mechanisms that underlie long-term symbiont persistence, and bacteriocyte homeostasis and maintenance. Nevertheless, while the Sanger sequencing methodology has significantly enhanced unigene number in $S$. oryzae, additional NGS needs to be realized in order to accurately analyze the transcriptome quantitatively, and to decipher the functions of interest to symbiosis at gene level.

As regards symbiont persistence, we have previously reported that one insect strategy to maintain long-term relationships with endosymbionts consists of compartmentalization of the bacteria into the bacteriocyte cells, which exhibit a local and structured immune response to tolerate the endosymbiont [6]. Indeed, while the experimental injection of the endosymbiont into the weevil hemolymph resulted in a drastic induction of genes encoding immune effectors, only a few immune genes were upregulated in the bacteriome, including the wpgrp 1 and the Tollip that are homologs to genes described as immune modulators $[6,53,83]$. The former is a homolog of the dipteran pgrp-lb gene, the expression of which downregulates the IMD pathway [76,84], and the latter was suspected of being a negative regulator of the vertebrate Toll pathway [53]. To gain a better insight into how IMD- and Toll-like pathways are regulated in the bacteriome tissue, we have examined the expression of additional genes identified in this work, which are branched at different levels of the signaling pathways. As a result, genes involved in the activation of IMD- and Toll-like pathways (i.e. imd, iap2, and ecsit) were highly expressed in the bacteriome, whereas the inhibitor cactus gene exhibited the opposite profile, which suggests that the IMD- and Toll-like pathways may potentially be activated in the Sitophilus bacteriome. This finding is initially intriguing since the end products of these pathways (i.e. the AMPs) are either absent or only weakly expressed in the bacteriome. However, taking into consideration that the Toll gene was first described as an essential component in establishing the dorsoventral axis in Drosophila embryo [85], and that IMD is connected with other cellular pathways, such as apoptosis [86], it is possible that IMD- and Toll-like pathways may be involved in developmental processes and in the homeostasis of symbiotic tissues. 
Such an assumption is supported by a similar immune pattern (i.e. high expression of Toll and low expression of AMPs) reported for the mutualistic association between Wolbachia and the parasitoid wasp, Asobara tabida [36]. However, the reason for the high expression of coleoptericin-A in the bacteriocyte is still unexplained. Whether IMD- and/or Toll-like pathways are branched on the coleoptericin-A synthesis pathway remains to be clarified from further investigations. Finally, while IMD- and Toll- like pathways seem to be activated in the bacteriocyte, it is possible that the inhibition of signal transduction by gene regulators is involved. For instance, wpgrp1 and tollip genes are good regulator candidates and they could play a crucial role in this inhibition [76,84]. Recently, Ryu et al. [75] have reported that the Drosophila homeobox gene caudal also regulates the commensal-gut bacteria by repressing the nuclear factor Kappa B-dependent AMP genes. Ongoing RNAi experiments will provide more information about the function and the regulation of these pathways in the Sitophilus system.

The high accumulation of transcripts from Rab7, Hrs and SNARE genes could be viewed as being due to intense endosomal trafficking within the bacteriocyte. These genes are certainly very involved in vesicle synthesis and fusion [62-64]. Moreover, intense vesicle trafficking has already been observed by electronic microscopy within Sitophilus bacteriocytes [30]. Vesicle trafficking may aid in metabolic component exchanges between the host and the symbiont, or it may help in endosome fusion, with late endosomes and lysozomes, to favor autophagy. For the latter, we can speculate about the possibility that autophagy could serve as an additional host mechanism to regulate symbiont density. In support of this hypothesis, in silico cDNA comparison between symbiont-full and symbiont-free ovaries has shown that vesicle trafficking is also highly represented in the presence of Wolbachia in the isopod Armadillidium vulgare [35]. Moreover, receptors of innate immunity have been identified on vertebrate endosome membranes $[57,87]$ and autophagy has been described as a possible means of eliminating intracellular pathogens [61].

To permanently sequester the endosymbiont within the bacteriome, and to avoid bacterial invasion into insect tissues, bacteriocyte cells need to maintain homeostasis and to survive during insect developmental stages. While apoptosis has been observed as a response to infection by a wide range of animal and plant pathogens $[88,89]$, very limited data are available on invertebrate symbiotic systems [70]. To tackle this question in the Sitophilus system, we have analyzed genes potentially involved in apoptosis inhibition (iap2 and iap3) and apoptosis execution (caspase-like). We have shown that the high expression of apoptosis inhibitor genes paralleled the low amount of caspase-like gene transcripts in the bacteriome. In addition to the upregulation of genes involved in cell growth, such as Ras and leonardo 14-3-3, these preliminary data suggest that weevil bacteriocytes manage to survive an endosymbiont infection by inhibiting the apoptosis pathway. Inhibition of apoptosis can also be mediated by the expression of the FK506BP gene (or FKBP). In vertebrates, the FKBP38 gene inhibits apoptosis by interacting with Bcl2 [90]. Moreover, we cannot exclude the possibility that apoptosis inhibition is manipulated by the symbiont for its own survival. Such a mechanism has been described in Asobara tabida, where Wolbachia elimination with antibiotic treatment led to the activation of apoptosis in female ovaries [5].

A striking result of this current study was that symbiotic larvae presented a lower immune response to bacterial challenge, when compared to aposymbiotic larvae.

Invertebrate immune reactions toward pathogens, and the possible evolutionary impact of endosymbiosis on shaping these reactions, have been the major focus of research in the past few years $[69,73,77,79-81]$. The recent genome sequencing of the pea aphid, which shares a long-term symbiotic relationship with the endosymbiont Buchnera, has surprisingly revealed that aphids lack crucial components of the IMD pathway [73]. Furthermore, no apparent AMP was determined by gene annotation [73,91]. In the same context, BraquartVarnier et al. [77] have shown that the cellular immune response could be affected by endosymbionts. Isopods harboring Wolbachia (wVulC) exhibited lower haemocyte density and more intense septicaemia in the haemolymph. In the ant, Camponotus fellah, insect treatment with the Rifampin antibiotic resulted in a drastic decrease in the number of symbiotic bacteria, and this decrease was associated with a higher encapsulation rate when compared with the non-treated insect control [92]. Diminished encapsulation ability in parasitoid Leptopilina eggs has also been reported, in the presence of Wolbachia, in D. simulans [93]. Taken together, these findings lead to the hypotheses that either invertebrate symbiosis may have selected for a simplification of the host immune system or endosymbionts manage to modulate the host immune expression, presumably for their own survival. A third hypothesis is that invertebrates might allocate different resources to immune pathways. In this case, the relatively low systemic response in weevil symbiotic larvae could be due to the allocation of insect resources to local expression of the bacteriome, to the detriment of the humoral systemic expression.

However, although these hypotheses appear to be compatible with our preliminary results on Sitophilus, 
additional work needs to be done to determine whether decreases in AMP gene expression in symbiotic insects are due to endosymbiont manipulation or whether heattreatment while obtaining apsoymbiotic insects has resulted in a genetic selection of host immunocompetence. Moreover, it is notable that the endosymbiosis interaction with the invertebrate immune system is an emerging field that provides quite contrasting data. Contrary to previous findings, several studies investigating Wolbachia as a potential control agent in vector insect species have reported that Wolbachia can activate the host immune system, and protect the insect against a wide variety of pathogens [79-82]. However, as only a few Wolbachia strains have been tested so far (i.e. $w$ MelPop and $w \mathrm{AlbB}$ ), and since many experiments were conducted on a heterologous host system, further investigations are needed to reveal whether insect immune activation is limited to some host-Wolbachia systems, or whether multiple strategies are being used by endosymbionts to ensure their own survival and to help their host to survive any pathogens.

In conclusion, this work provides a large repertoire of S. oryzae EST coding sequences that will help in future molecular and functional investigations, both into symbiosis and other topics related to insect physiology and development. Transcriptomic analyses have elucidated the bacteriome local immune response and indicated new cellular regulations of potential interest in intracellular symbiosis. Moreover, data provided on host immunocompetence variations in relation to symbiosis broaden and reinforce the idea that invertebrate symbiotic associations may have shaped some host immune functions. This work should stimulate further genetic and functional studies to determine how immunity is modified to accommodate the symbiont partner and how endosymbionts manipulate the immune response for their own survival and to enable the host to resist pathogens.

\section{Additional material}

Additional file 1: Primers used for transcriptomic study

Additional file 2: Results of functional enrichment on SSHA and SSHB

Additional file 3: Eukaryotic sequences generated in SSHA

Additional file 4: Characteristics of sequences used in transcriptomic study

\section{Acknowledgments}

We gratefully acknowledge M. S. Méresse for providing Salmonella typhimurium strains and V. James for the English corrections. The authors would also like to thank the anonymous reviewers for their constructive criticisms. SSH, non-normalized and normalized libraries were realized by the Evrogen Company (Moscow, Russia). S. oryzae EST sequences were obtained within the framework of the program "Functional Genomics and Immune Signaling in Invertebrate Endosymbiosis" coordinated by $\mathrm{AH}$ in collaboration with the "Centre National de Séquençage, Genoscope" (Evry, France). This work was supported by INRA, INSA de Lyon, the French Agence Nationale de la Recherche (ANR-06-BLANC-0316 "EndoSymbArt", ANR-2010-BLAN170101 "ImmunSymbArt") and the COST action FA0701 (Arthropod Symbioses).

This article has been published as part of BMC Microbiology Volume 11 Supplement 1, 2012: Arthropod symbioses: from fundamental studies to pest and disease mangement. The full contents of the supplement are available online at http://www.biomedcentral.com/1471-2180/12?issue=S1.

\section{Author details}

${ }^{1}$ INSA-Lyon, UMR203 BF2I, INRA, Biologie Fonctionnelle Insectes et Interactions, Bat. Louis-Pasteur 20 ave. Albert Einstein, F-69621 Villeurbanne, France. ${ }^{2}$ UMR CNRS 5558 Laboratoire de Biométrie et Biologie Evolutive, Université Claude Bernard Lyon, F-69621 Villeurbanne, France. ${ }^{3}$ Commissariat à l'Énergie Atomique (CEA), Genoscope (Centre National de Séquençage), 2 rue Gaston Crémieux, CP 5706, 91,057 Evry Cedex, France.

\section{Authors' contributions}

AV designed and performed experiments, analyzed data (statistics and bioinformatics), wrote the paper and participated in bioinformatic analysis; DC set up the bioinformatic tools and analyzed all the libraries and EST sequences; CVM participated in the construction of the libraries and the molecular study, performed the insect challenge experiment with Salmonella and performed RNA extraction; AVa carried out dissections and qRT-PCR; FG and PW realized EST sequences; $\mathrm{AH}$ conceived the study, coordinated the work and helped to draft and write the manuscript.

All authors have read and approved the final manuscript.

\section{Competing interests}

The authors declare that they have no competing interests.

Published: 18 January 2012

\section{References}

1. O'Neill SL, Karr TL: Bidirectional incompatibility between conspecific populations of Drosophila simulans. Nature 1990, 348(6297):178-180.

2. Stouthamer R, Breeuwert JA, Luck RF, Werren JH: Molecular identification of microorganisms associated with parthenogenesis. Nature 1993, 361(6407):66-68.

3. Heddi A, Grenier AM, Khatchadourian C, Charles H, Nardon P: Four intracellular genomes direct weevil biology: nuclear, mitochondrial, principal endosymbiont, and Wolbachia. Proc Natl Acad Sci U S A 1999, 96(12):6814-6819.

4. Miller WJ, Ehrman L, Schneider D: Infectious speciation revisited: impact of symbiont-depletion on female fitness and mating behavior of Drosophila paulistorum. PLoS Pathog 2010, 6(12):e1001214.

5. Pannebakker BA, Loppin B, Elemans CP, Humblot L, Vavre F: Parasitic inhibition of cell death facilitates symbiosis. Proc Natl Acad Sci U S A 2007, 104(1):213-215.

6. Anselme C, Perez-Brocal V, Vallier A, Vincent-Monegat C, Charif D, Latorre A, Moya $A$, Heddi A: Identification of the weevil immune genes and their expression in the bacteriome tissue. BMC Biol 2008, 6:43.

7. Kremer N, Voronin D, Charif D, Mavingui P, Mollereau B, Vavre F: Wolbachia interferes with ferritin expression and iron metabolism in insects. PLOS Pathog 2009, 5(10):e1000630.

8. Reynolds S, Rolff J: Immune function keeps endosymbionts under control. J Biol 2008, 7(8):28.

9. Oliver KM, Russell JA, Moran NA, Hunter MS: Facultative bacterial symbionts in aphids confer resistance to parasitic wasps. Proc Natl Acad Sci U S A 2003, 100(4):1803-1807.

10. Tsuchida T, Koga R, Horikawa M, Tsunoda T, Maoka T, Matsumoto S, Simon JC, Fukatsu T: Symbiotic bacterium modifies aphid body color. Science 2010, 330(6007):1102-1104.

11. Lefevre C, Charles H, Vallier A, Delobel B, Farrell B, Heddi A: Endosymbiont phylogenesis in the dryophthoridae weevils: evidence for bacterial replacement. Mol Biol Evol 2004, 21(6):965-973.

12. Conord C, Despres L, Vallier A, Balmand S, Miquel C, Zundel S, Lemperiere $G$, Heddi A: Long-term evolutionary stability of bacterial 
endosymbiosis in curculionoidea: additional evidence of symbiont replacement in the dryophthoridae family. Mol Biol Evol 2008, 25(5):859-868.

13. Moran N, Baumann P: Phylogenetics of cytoplasmically inherited microorganisms of arthropods. Trends Ecol Evol 1994, 9(1):15-20.

14. Gomez-Valero L, Soriano-Navarro M, Perez-Brocal V, Heddi A, Moya A, Garcia-Verdugo JM, Latorre A: Coexistence of Wolbachia with Buchnera aphidicola and a secondary symbiont in the aphid Cinara cedri. J Bacteriol 2004, 186(19):6626-6633.

15. Shigenobu S, Watanabe H, Hattori M, Sakaki Y, Ishikawa H: Genome sequence of the endocellular bacterial symbiont of aphids Buchnera sp. APS. Nature 2000, 407(6800):81-86.

16. Gil R, Silva FJ, Zientz E, Delmotte F, Gonzalez-Candelas F, Latorre A, Rausell C, Kamerbeek J, Gadau J, Holldobler B, et al: The genome sequence of Blochmannia floridanus: comparative analysis of reduced genomes. Proc Natl Acad Sci USA 2003, 100(16):9388-9393.

17. Gil R, Belda E, Gosalbes MJ, Delaye L, Vallier A, Vincent-Monegat C, Heddi A, Silva FJ, Moya A, Latorre A: Massive presence of insertion sequences in the genome of SOPE, the primary endosymbiont of the rice weevil Sitophilus oryzae. Int Microbiol 2008, 11(1):41-48.

18. Weiss BL, Wu Y, Schwank JJ, Tolwinski NS, Aksoy S: An insect symbiosis is influenced by bacterium-specific polymorphisms in outer-membrane protein A. Proc Natl Acad Sci U S A 2008, 105(39):15088-15093.

19. Boutros $M$, Agaisse $H$, Perrimon N: Sequential activation of signaling pathways during innate immune responses in Drosophila. Dev Cell 2002 3(5):711-722

20. Lemaitre B, Hoffmann J: The host defense of Drosophila melanogaster. Annu Rev Immunol 2007, 25:697-743.

21. Lazzaro BP: Natural selection on the Drosophila antimicrobial immune system. Curr Opin Microbiol 2008, 11(3):284-289.

22. Zhuang $Z H$, Sun L, Kong L, Hu JH, Yu MC, Reinach P, Zang JW, Ge BX: Drosophila TAB2 is required for the immune activation of JNK and NFkappaB. Cell Signal 2006, 18(7):964-970.

23. Gesellchen V, Kuttenkeuler D, Steckel M, Pelte N, Boutros M: An RNA interference screen identifies Inhibitor of Apoptosis Protein 2 as a regulator of innate immune signalling in Drosophila. EMBO Rep 2005, 6(10):979-984

24. Huh JR, Foe I, Muro I, Chen CH, Seol JH, Yoo SJ, Guo M, Park JM, Hay BA: The Drosophila inhibitor of apoptosis (IAP) DIAP2 is dispensable for cell survival, required for the innate immune response to gram-negative bacterial infection, and can be negatively regulated by the reaper/hid/ grim family of IAP-binding apoptosis inducers. J Biol Chem 2007, 282(3):2056-2068.

25. Valanne S, Kleino A, Myllymaki $\mathrm{H}$, Vuoristo J, Ramet M: lap2 is required for a sustained response in the Drosophila Imd pathway. Dev Comp Immunol 2007, 31(10):991-1001.

26. Leulier F, Rodriguez A, Khush RS, Abrams JM, Lemaitre B: The Drosophila caspase Dredd is required to resist gram-negative bacterial infection. EMBO Rep 2000, 1(4):353-358.

27. Leulier F, Vidal S, Saigo K, Ueda R, Lemaitre B: Inducible expression of double-stranded RNA reveals a role for dFADD in the regulation of the antibacterial response in Drosophila adults. Curr Biol 2002, 12(12):996-1000

28. Stoven S, Ando I, Kadalayil L, Engstrom Y, Hultmark D: Activation of the Drosophila NF-kappaB factor Relish by rapid endoproteolytic cleavage. EMBO Rep 2000, 1(4):347-352.

29. Stoven $S$, Silverman $N$, Junell $A$, Hedengren-Olcott $M$, Erturk D, Engstrom $Y$, Maniatis T. Hultmark D: Caspase-mediated processing of the Drosophila NF-kappaB factor Relish. Proc Natl Acad Sci U S A 2003, 100(10):5991-5996.

30. Heddi A, Vallier A, Anselme C, Xin H, Rahbe Y, Wackers F: Molecular and cellular profiles of insect bacteriocytes: mutualism and harm at the initial evolutionary step of symbiogenesis. Cell Microbiol 2005, 7(2):293-305

31. Heddi A, Charles H, Khatchadourian C, Bonnot G, Nardon P: Molecular characterization of the principal symbiotic bacteria of the weevil Sitophilus oryzae: a peculiar G + C content of an endocytobiotic DNA. J Mol Evol 1998, 47(1):52-61.

32. Charles $\mathrm{H}$, Heddi A, Rahbe Y: A putative insect intracellular endosymbiont stem clade, within the Enterobacteriaceae, infered from phylogenetic analysis based on a heterogeneous model of DNA evolution. C R Acad Sci III 2001, 324(5):489-494.
33. Charles H, Heddi A, Guillaud J, Nardon C, Nardon P: A molecular aspect of symbiotic interactions between the weevil Sitophilus oryzae and its endosymbiotic bacteria: over-expression of a chaperonin. Biochem Biophys Res Commun 1997, 239(3):769-774.

34. Dale C, Plague GR, Wang B, Ochman H, Moran NA: Type III secretion systems and the evolution of mutualistic endosymbiosis. Proc Natl Acad Sci U S A 2002, 99(19):12397-12402.

35. Chevalier F, Herbinière-Gaboreau J, Charif $D$, Mitta G, Gavory F, Wincker $P$, Grève $P$, Braquart-Varnier $C$, Bouchon D: Feminizing Wolbachia: A transcriptomics approach with insights on the immune response genes in Armadillidium vulgare. BMC Microbiol 2012, 12(Suppl 1):S1.

36. Kremer N, Charif D, Henri H, Gavory F, Wincker P, Mavingui P, Vavre F: Wolbachia influence on host gene expression in an obligatory symbiosis. BMC Microbiol 2012, 12(Suppl 1):S7

37. Nardon P: Obtention d'une souche asymbiotique chez le charançon Sitophilus sasakii Tak: différentes méthodes d'obtention et comparaison avec la souche symbiotique d'origine. C R Acad Sci Paris 1973, 277(D):981-984.

38. Rebrikov DV, Britanova OV, Gurskaya NG, Lukyanov KA, Tarabykin VS, Lukyanov SA: Mirror orientation selection (MOS): a method for eliminating false positive clones from libraries generated by suppression subtractive hybridization. Nucleic acids research 2000, 28(20):E90.

39. Zhu Y, Johnson TJ, Myers AA, Kanost MR: Identification by subtractive suppression hybridization of bacteria-induced genes expressed in Manduca sexta fat body. Insect Biochem Mol Biol 2003, 33(5):541-559.

40. Zhulidov PA, Bogdanova EA, Shcheglov AS, Vagner LL, Khaspekov GL, Kozhemyako VB, Matz MV, Meleshkevitch E, Moroz LL, Lukyanov SA, et al: Simple cDNA normalization using kamchatka crab duplex-specific nuclease. Nucleic Acids Res 2004, 32(3):e37.

41. Shagin DA, Rebrikov DV, Kozhemyako VB, Altshuler IM, Shcheglov AS, Zhulidov PA, Bogdanova EA, Staroverov DB, Rasskazov VA, Lukyanov S: A novel method for SNP detection using a new duplex-specific nuclease from crab hepatopancreas. Genome Res 2002, 12(12):1935-1942.

42. Ewing B, Green P: Base-calling of automated sequencer traces using phred. II. Error probabilities. Genome Res 1998, 8(3):186-194.

43. Ewing B, Hillier L, Wendl MC, Green P: Base-calling of automated sequencer traces using phred. I. Accuracy assessment. Genome Res 1998, 8(3):175-185.

44. Pertea G, Huang X, Liang F, Antonescu V, Sultana R, Karamycheva S, Lee $Y$, White J, Cheung F, Parvizi B, et al: TIGR Gene Indices clustering tools (TGICL): a software system for fast clustering of large EST datasets. Bioinformatics 2003, 19(5):651-652.

45. Conesa A, Gotz S, Garcia-Gomez JM, Terol J, Talon M, Robles M: Blast2GO: a universal tool for annotation, visualization and analysis in functional genomics research. Bioinformatics 2005, 21(18):3674-3676.

46. Gotz S, Garcia-Gomez JM, Terol J, Williams TD, Nagaraj SH, Nueda MJ, Robles M, Talon M, Dopazo J, Conesa A: High-throughput functional annotation and data mining with the Blast2GO suite. Nucleic Acids Res 2008, 36(10):3420-3435

47. Stekel DJ, Git Y, Falciani F: The comparison of gene expression from multiple CDNA libraries. Genome Res 2000, 10(12):2055-2061.

48. Al-Shahrour F, Diaz-Uriarte R, Dopazo J: FatiGO: a web tool for finding significant associations of Gene Ontology terms with groups of genes. Bioinformatics 2004, 20(4):578-580.

49. Vallier A, Vincent-Monegat C, Laurencon A, Heddi A: RNAi in the cereal weevil Sitophilus spp: systemic gene knockdown in the bacteriome tissue. BMC Biotechnol 2009, 9:44

50. Pfaffl MW, Horgan GW, Dempfle L: Relative expression software tool (REST) for group-wise comparison and statistical analysis of relative expression results in real-time PCR. Nucleic Acids Res 2002, 30(9):e36.

51. Pfaffl MW, Tichopad A, Prgomet C, Neuvians TP: Determination of stable housekeeping genes, differentially regulated target genes and sample integrity: BestKeeper-Excel-based tool using pair-wise correlations. Biotechnol Lett 2004, 26(6):509-515.

52. Richards S, Gibbs RA, Weinstock GM, Brown SJ, Denell R, Beeman RW, Gibbs R, Bucher G, Friedrich M, Grimmelikhuijzen CJ, et al: The genome of the model beetle and pest Tribolium castaneum. Nature 2008, 452(7190):949-955.

53. Zhang G, Ghosh S: Negative regulation of toll-like receptor-mediated signaling by Tollip. J Biol Chem 2002, 277(9):7059-7065 . 
54. Lemaitre B, Kromer-Metzger E, Michaut L, Nicolas E, Meister M, Georgel P, Reichhart JM, Hoffmann JA: A recessive mutation, immune deficiency (imd), defines two distinct control pathways in the Drosophila host defense. Proc Natl Acad Sci U S A 1995, 92(21):9465-9469.

55. Lemaitre B, Nicolas E, Michaut L, Reichhart JM, Hoffmann JA: The dorsoventral regulatory gene cassette spatzle/Toll/cactus controls the potent antifungal response in Drosophila adults. Cell 1996, 86(6):973-983.

56. Kopp E, Medzhitov R, Carothers J, Xiao C, Douglas I, Janeway CA, Ghosh S: ECSIT is an evolutionarily conserved intermediate in the Toll/IL-1 signal transduction pathway. Genes Dev 1999, 13(16):2059-2071.

57. Akira S, Takeda K: Toll-like receptor signalling. Nat Rev Immunol 2004, 4(7):499-511.

58. Wood KW, Sarnecki C, Roberts TM, Blenis J: ras mediates nerve growth factor receptor modulation of three signal-transducing protein kinases: MAP kinase, Raf-1, and RSK. Cell 1992, 68(6):1041-1050.

59. Li W, Skoulakis EM, Davis RL, Perrimon N: The Drosophila 14-3-3 protein Leonardo enhances Torso signaling through D-Raf in a Ras 1-dependent manner. Development 1997, 124(20):4163-4171.

60. Kahl CR, Means AR: Regulation of cell cycle progression by calcium/ calmodulin-dependent pathways. Endocr Rev 2003, 24(6):719-736.

61. Yano T, Mita S, Ohmori H, Oshima Y, Fujimoto Y, Ueda R, Takada H, Goldman WE, Fukase K, Silverman N, et al: Autophagic control of listeria through intracellular innate immune recognition in drosophila. Nat Immunol 2008, 9(8):908-916.

62. McNew JA, Parlati F, Fukuda $R$, Johnston RJ, Paz K, Paumet F, Sollner $T H$ Rothman JE: Compartmental specificity of cellular membrane fusion encoded in SNARE proteins. Nature 2000, 407(6801):153-159.

63. Feng $Y$, Press B, Chen W, Zimmerman J, Wandinger-Ness A: Expression and properties of Rab7 in endosome function. Methods Enzymol 2001, 329:175-187.

64. Lloyd TE, Atkinson R, Wu MN, Zhou Y, Pennetta G, Bellen HJ: Hrs regulates endosome membrane invagination and tyrosine kinase receptor signaling in Drosophila. Cell 2002, 108(2):261-269.

65. Logdberg L, Wester L: Immunocalins: a lipocalin subfamily that modulates immune and inflammatory responses. Biochim Biophys Acta 2000, 1482(1-2):284-297.

66. Flo TH, Smith KD, Sato S, Rodriguez DJ, Holmes MA, Strong RK, Akira S, Aderem A: Lipocalin 2 mediates an innate immune response to bacterial infection by sequestrating iron. Nature 2004, 432(7019):917-921.

67. Fang LY, Wong TY, Chiang WF, Chen YL: Fatty-acid-binding protein 5 promotes cell proliferation and invasion in oral squamous cell carcinoma. J Oral Pathol Med 2010, 39(4):342-348.

68. Pais R, Lohs $C$, Wu Y, Wang J, Aksoy S: The obligate mutualist Wigglesworthia glossinidia influences reproduction, digestion, and immunity processes of its host, the tsetse fly. Appl Environ Microbiol 2008, 74(19):5965-5974.

69. Gross R, Vavre F, Heddi A, Hurst GD, Zchori-Fein E, Bourtzis K: Immunity and symbiosis. Mol Microbiol 2009, 73(5):751-759.

70. Troll JV, Adin DM, Wier AM, Paquette N, Silverman N, Goldman WE, Stadermann FJ, Stabb EV, McFall-Ngai MJ: Peptidoglycan induces loss of a nuclear peptidoglycan recognition protein during host tissue development in a beneficial animal-bacterial symbiosis. Cell Microbiol 2009, 11(7):1114-1127.

71. Anbutsu H, Fukatsu T: Evasion, suppression and tolerance of Drosophila innate immunity by a male-killing Spiroplasma endosymbiont. Insect $\mathrm{Mol}$ Biol 2010, 19(4):481-488.

72. Douglas $A E$, Bouvaine $S$, Russell RR: How the insect immune system interacts with an obligate symbiotic bacterium. Proc Biol Sci 2010, 278(1704):333-338.

73. Gerardo NM, Altincicek B, Anselme C, Atamian H, Barribeau SM, de Vos M, Duncan EJ, Evans JD, Gabaldon T, Ghanim M, et al: Immunity and other defenses in pea aphids, Acyrthosiphon pisum. Genome Biol 2010, 11(2): R21.

74. Anselme C, Vallier A, Balmand S, Fauvarque MO, Heddi A: Host PGRP gene expression and bacterial release in endosymbiosis of the weevil Sitophilus zeamais. App/ Environ Microbiol 2006, 72(10):6766-6772.

75. Ryu JH, Kim SH, Lee HY, Bai JY, Nam YD, Bae JW, Lee DG, Shin SC, Ha EM, Lee $\mathrm{WJ}$ : Innate immune homeostasis by the homeobox gene caudal and commensal-gut mutualism in Drosophila. Science 2008, 319(5864):777-782.
76. Wang J, Wu Y, Yang G, Aksoy S: Interactions between mutualist Wigglesworthia and tsetse peptidoglycan recognition protein (PGRP-LB) influence trypanosome transmission. Proc Natl Acad Sci U S A 2009, 106(29):12133-12138

77. Braquart-Varnier C, Lachat $M$, Herbiniere J, Johnson M, Caubet $Y$, Bouchon D, Sicard M: Wolbachia mediate variation of host immunocompetence. PLoS One 2008, 3(9):e3286.

78. Hedges LM, Brownlie JC, O'Neill SL, Johnson KN: Wolbachia and virus protection in insects. Science 2008, 322(5902):702

79. Teixeira L, Ferreira A, Ashburner M: The bacterial symbiont Wolbachia induces resistance to RNA viral infections in Drosophila melanogaster. PLoS Biol 2008, 6(12):e2.

80. Kambris Z, Cook PE, Phuc HK, Sinkins SP: Immune activation by lifeshortening Wolbachia and reduced filarial competence in mosquitoes. Science 2009, 326(5949):134-136.

81. Moreira LA, Iturbe-Ormaetxe I, Jeffery JA, Lu G, Pyke AT, Hedges LM Rocha BC, Hall-Mendelin S, Day A, Riegler M, et al: A Wolbachia symbiont in Aedes aegypti limits infection with dengue, Chikungunya, and Plasmodium. Cell 2009, 139(7):1268-1278.

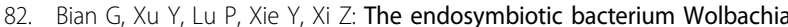
induces resistance to dengue virus in Aedes aegypti. PLoS Pathog 2010, 6(4):e1000833

83. Burns K, Clatworthy J, Martin L, Martinon F, Plumpton C, Maschera B, Lewis A, Ray K, Tschopp J, Volpe F: Tollip, a new component of the IL-1RI pathway, links IRAK to the IL-1 receptor. Nat Cell Biol 2000, 2(6):346-351.

84. Zaidman-Remy A, Herve M, Poidevin M, Pili-Floury S, Kim MS, Blanot D, Oh BH, Ueda R, Mengin-Lecreulx D, Lemaitre B: The Drosophila amidase PGRP-LB modulates the immune response to bacterial infection. Immunity 2006, 24(4):463-473.

85. Belvin MP, Anderson KV: A conserved signaling pathway: the Drosophila toll-dorsal pathway. Annu Rev Cell Dev Biol 1996, 12:393-416.

86. Georgel P, Naitza S, Kappler C, Ferrandon D, Zachary D, Swimmer C, Kopczynski C, Duyk G, Reichhart JM, Hoffmann JA: Drosophila immune deficiency (IMD) is a death domain protein that activates antibacterial defense and can promote apoptosis. Dev Cell 2001, 1(4):503-514

87. Hemmi $H$, Takeuchi $O$, Kawai $T$, Kaisho T, Sato $S$, Sanjo $H$, Matsumoto $M$ Hoshino K, Wagner $\mathrm{H}$, Takeda $\mathrm{K}$, et al: A Toll-like receptor recognizes bacterial DNA. Nature 2000, 408(6813):740-745.

88. Lam E, Kato N, Lawton M: Programmed cell death, mitochondria and the plant hypersensitive response. Nature 2001, 411(6839):848-853.

89. Labbe K, Saleh M: Cell death in the host response to infection. Cell Death Differ 2008, 15(9):1339-1349.

90. Shirane M, Nakayama Kl: Inherent calcineurin inhibitor FKBP38 targets $\mathrm{BCl}-2$ to mitochondria and inhibits apoptosis. Nat Cell Biol 2002, 5(1):28-37.

91. Genome sequence of the pea aphid Acyrthosiphon pisum. PLoS Biol 2010, 8(2):e1000313.

92. de Souza DJ, Bezier A, Depoix D, Drezen JM, Lenoir A: Blochmannia endosymbionts improve colony growth and immune defence in the ant Camponotus fellah. BMC Microbiol 2009, 9:29

93. Fytrou A, Schofield PG, Kraaijeveld AR, Hubbard SF: Wolbachia infection suppresses both host defence and parasitoid counter-defence. Proceedings Biological sciences / The Royal Society 2006, 273(1588):791-796.

doi:10.1186/1471-2180-12-S1-S14

Cite this article as: Vigneron et al: Host gene response to endosymbiont and pathogen in the cereal weevil Sitophilus oryzae. BMC Microbiology 2012 12(Suppl 1):S14 